\title{
Short-Term Influence of Burning on Species Abundance, Biomass Production, Wood Plant Density and Browsing Unit in an Albany Thicket of the Eastern Cape, South Africa
}

\author{
Sive Tokozwayo ${ }^{*}$ (D), Thubela Thubela1, Masibonge Gxasheka ${ }^{2}$, Siza Mthi' ${ }^{1}$, Unathi Gulwa ${ }^{1}$, \\ Nkululeko Nyangiwe ${ }^{1,3}$, Ayanda Kwaza ${ }^{4}$, Nokonwaba Jokani' ${ }^{1}$, Nobulungisa Mgujulwa', \\ Yanga Mkabile5, Thozama Theophilus Bozo5 ${ }^{5}$, Amahle Sogoni ${ }^{1}$ \\ ${ }^{1}$ Döhne Agricultural Development Institute, Department of Rural Development and Agrarian Reform, \\ Stutterheim, South Africa \\ ${ }^{2}$ Department of Plant Production, Soil Science \& Agricultural Engineering, University of Limpopo, \\ Polokwane, South Africa \\ ${ }^{3}$ Department of Agriculture and Animal Health, University of South Africa, Florida, South Africa \\ ${ }^{4}$ Department of Rural Development and Agrarian Reform, Land Use Management, Gqeberha, South Africa \\ ${ }^{5}$ Department of Rural Development and Agrarian Reform, Bathurst, South Africa \\ Email: ^furaluke@gmail.com
}

How to cite this paper: Tokozwayo, S., Thubela, T., Gxasheka, M., Mthi, S., Gulwa, U., Nyangiwe, N., Kwaza, A., Jokani, N., Mgujulwa, N., Mkabile, Y., Bozo, T.T. and Sogoni, A. (2022) Short-Term Influence of Burning on Species Abundance, Biomass Production, Wood Plant Density and Browsing Unit in an Albany Thicket of the Eastern Cape, South Africa. Agricultural Sciences, 13, 74-85.

https://doi.org/10.4236/as.2022.131007

Received: November 9, 2021

Accepted: January 25, 2022

Published: January 28, 2022

Copyright $\odot 2022$ by author(s) and Scientific Research Publishing Inc. This work is licensed under the Creative Commons Attribution International License (CC BY 4.0).

http://creativecommons.org/licenses/by/4.0/

\begin{abstract}
Fire is regarded as management practice for maintaining grasslands and savannas. The vegetation occurring in fire prone areas becomes highly adapted to fire occurrences in savannas and grasslands. However, documentation on the influence of burning on vegetation is still limited in an albany thicket biome. The aim of the study was to evaluate the short-term influence of burning on species abundance, biomass production, wood plant density and browsing unit. Six plots $\left(2500 \mathrm{~m}^{2}\right)$ were demarcated; in each plot two parallel transects of $120 \mathrm{~m}^{2}$ with $5 \mathrm{~m}$ distance apart were measured. Three plots were burned in spring season, while no burning was done on the other remaining plots. Forty points per plot were obtained using step-point method to determine the relative abundance at burned and unburned plots. Woody plants occurred within a transect were identified, counted and recorded to determine density and browsing unit. Three quadrats (i.e. $0.25 \mathrm{~m}^{2}$ ) per plot were randomly laid within the transect; aboveground plant material within a quadrat were harvested. A total of 18 samples were harvested and oven dried at $60^{\circ} \mathrm{C}$ for 48 hours to determine biomass production. The results showed that Themeda triandra (14\%) and Panicum maximum (10\%) were most abun-
\end{abstract}


dant grass species at the burned plots. Burned plots had significantly higher biomass production (4804 kg/ha) compared to unburned plots $(3641 \mathrm{~kg} / \mathrm{ha})$. Vachellia karoo (burned: 65.85\% \& unburn: 13.70\%) and Searsia pallens (burned: $26.83 \%$ \& unburned: $6.85 \%$ ) were most dominant wood plant species at both burned and unburned plots. Burned plots had the highest browsing unit $(3221 \mathrm{BU} / \mathrm{ha})$ compared to unburned plots $(2058 \mathrm{BU} / \mathrm{ha})$. The decrease of woody plants at the burned plots proved that fire has a tremendous potential for managing woody plants. This study provided information on short-term influence of burning, however further long-term trials are required to determine the effects of burning.

\section{Keywords}

Burning, Browsing, Density, Relative Abundance

\section{Introduction}

Bush encroachment is described as an increase in the abundance of woody vegetation and in savanna and grassland biomes [1]. Encroachment is perceived as the most extensive forms of degradation and a globally threat to the savanna and grassland biomes in both semi-arid and arid regions [2] [3] [4]. In South Africa, the estimated affected lands by bush encroachment are approximately 7.3 million hectares [5]. Ecologists perceived bush encroachment as a beneficiary in terms of carbon capture and storage [6]. However, it may also permanently change the structure and functioning of savanna ecosystem [1].

The drivers of bush encroachment are complex to be understood, but are associated with overgrazing, climate related factors, exclusion of both burning and browsers [7]. Prescribed burning is only the cheapest tool which can be used to reduce the density of woody plants [8] [9]. Fire has a greater potential for improving species diversity, forage quality and biomass production in savanna ecosystems [8]. Globally, burning is done for removing grass litter or moribund, reducing tick infestation on grasses, controlling undesirable plants and improving grass quality in terms of nutrient content [8].

Burning may also reduce light-limitations created by litter or woody plant cover, in that way grasses may receive more radiant energy which is vital for photosynthesis. Use of fire also improves nitrogen mineralization from organic matter [8]. [10] demonstrated that burning can easily influence of vegetation structure and functioning of the ecosystem by suppressing the establishment of less fire tolerance species. Burning has been considered as an important agent in shaping savannas and grasslands in terms of vegetation composition [11]. Contrast, long term trial on manipulation of fire frequency and fire exclusion show no significant difference in terms of woody plant density [12].

Prescribed burning may suppress sapling from growing to maturity and producing seeds [13]. Despite woody plant density, fire has shown a significant in- 
fluenced on the woody vegetation structure [14]. Contrast, fire has shown significant on the woody plant species composition [14]. Burning under wet savannas may become more effective in reducing tree density due to high fuel load production compared to the dry savannas [15] [16]. In Eastern Cape, albany thicket biome is characterized by the dominance of perennial grasses, succulent euphorbias, aloes with a thick understory composed thorny shrubs, woody lians, shrubby succulents, succulent herbaceous vegetation and tress. Due to uncontrolled thickness of understory or density, forage material is not easily accessible. Such has resulted in a decline of grazing capacity and poor performance large stock units in albany thicket biome. The aim of study was to assess the influence of short-term burning on herbaceous vegetation and woody plants in albany thicket biome of the Eastern Cape.

\section{Materials and Methods}

\subsection{Site Description}

Bathurst burning trial is situated at $33^{\circ} 32^{\prime} 42.83^{\prime \prime} S$; $26^{\circ} 50^{\prime} 25.24 " \mathrm{E}$ with elevation of $126 \mathrm{~m}$, under Ndlambe Local Municipality in Sarah Baartman District (previously known as Cacadu District) of the Eastern Cape province (Figure 1). In

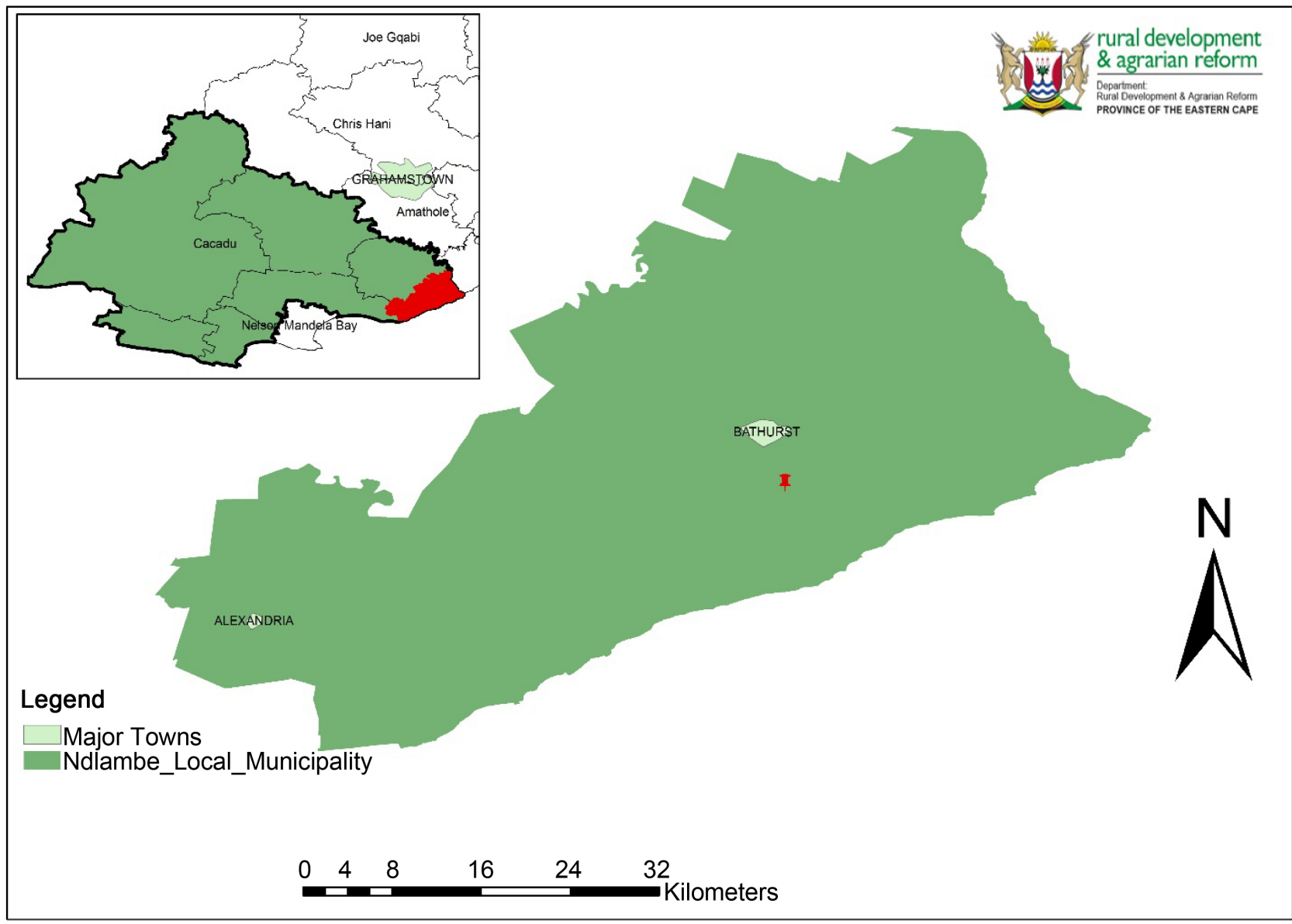

Figure 1. The map of the study site in Ndlambe local municipality under the Sarah baartman district in the eastern cape province. 
terms of vegetation, Bathurst falls under the kowie thicket veld type (i.e. albany thicket biome) [17]. Kowie thicket is characterized by grasses, succulent vegetation, shrubs and trees [17]. Soil parent material was that of sandstone and shale [17].

\subsection{Experimental Layout and Data Collection}

The research was conducted in the Eastern Cape at Bathurst Agricultural Research Station. In terms of grazing and browsing, the research was carried out in a protected area of the kowie thicket veld type. The experiment site was chosen since the vegetation was similar in terms of encroachment. Six plots were demarcated marked within the area 10 hectares, three of which were assigned to controlled burning and three of which were left unburned. The burning was done in early spring season before the first rain as suggested by [18]. In this study, head fire was employed as recommended by [18]. The burning, the Ndlambe Local Municipality (i.e. Fire and Rescue Department) assessed relative humidity, temperatures, and wind in accordance with the National Veld and Forest Act 101 of 1998. The burning occurred in September 2018 and September 2019.

Vegetation sampling was done at the beginning of spring prior burning in September 2019 (Figure 2) and 2020, respectively. In each plot, a two parallel permanent belt transect of $3 \mathrm{~m} \times 40 \mathrm{~m}$ with a $15 \mathrm{~m}$ distance apart were marked using tape-measure and iron rods. To determine woody plants relative abundance percentage, woody plant density and browsing unit, all woody plants occurring within each belt transect were identified, counted and recorded. For herbaceous vegetation, a total of 40 points were estimated using step point technique within each belt transect. A metal rod lowered every two steps, hit or nearest species were identified and recorded to determine relative abundance percentage and grass species composition according to [19] [20] [21].

Furthermore, grasses were classified according their ecological grouping, perenniality and nutritional value using Grasses of Southern Africa guide [19] [20] [22]. In each plot $0.5 \mathrm{~m} \times 0.5 \mathrm{~m}$ quadrant was randomly laid 3 times and aboveground plant materials within a quadrat were harvested to using scissors. A total of 18 samples were harvested to determine biomass production and all samples

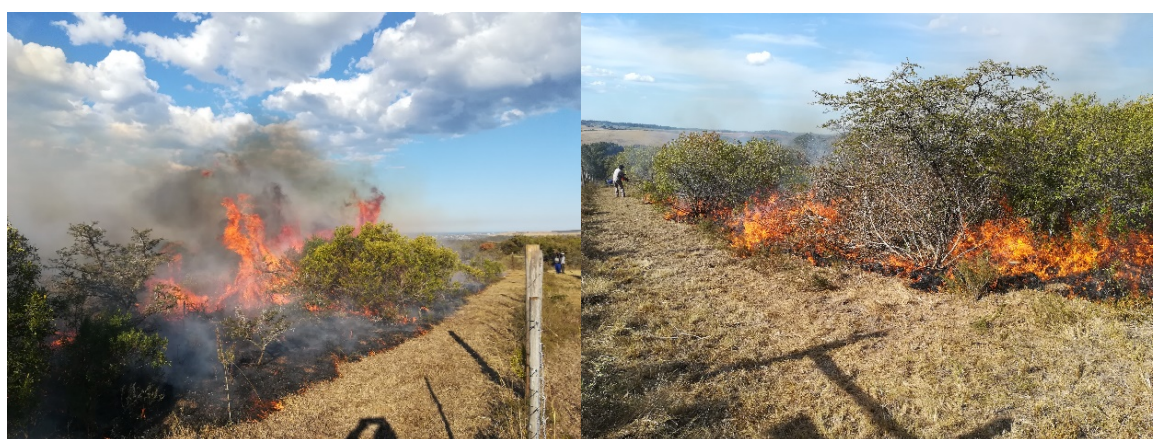

Figure 2. During the burning at Bathurst burning trial in September 2019. 
were oven dried at $60^{\circ} \mathrm{C}$ for 48 hours [22] [23]. Dried samples were weighted, converted to from $\mathrm{g} / \mathrm{m}^{2}$ to $\mathrm{kg} / \mathrm{ha}$ and biomass production was determined as $\mathrm{kg} / \mathrm{ha}$. Woody plants within the belt transect were identified, counted and recorded to determine woody plants relative abundance percentage, woody plant density and browsing unit.

\subsection{Data Analysis}

A one-way ANOVA was performed using [24], version 9.1 to test the difference of biomass production in both burned and unburned sites at $95 \%$ confident interval. Descriptive statistics were performed using excel to determine relative abundance percentages of plant species in both burned and unburned sites.

The relative abundance was calculated according to [20] [25] as follows:

$$
\text { Relative abundance }(\%)=\frac{\text { Number of individual species }}{\text { Number of species population }} \times 100 \%
$$

Bush density was calculated according to [20] [25] as follows:

$$
\mathrm{BD}=\mathrm{N}_{\mathrm{WPT}} \times \mathrm{S}_{\mathrm{T}}
$$

where $\mathrm{BD}=$ Bush density, $\mathrm{N}_{\mathrm{WPT}}=$ number of woody plants within the transect, $\mathrm{S}_{\mathrm{T}}=$ Size of the transect. Browsing unit was determined according to [25], acceptable or browseable woody plants at the height of $1.5 \mathrm{~m}$ or less were added together to determine the browsing unit (BU/ha). According to [20] [25] represents the browseable woody plants that are available to be browsed by goats at the height of $\leq 1.5 \mathrm{~m}$ of the soil surface.

\section{Results and Discussion}

\subsection{Effect of Burning on Species Composition}

A total of 15 plant species were recorded, consisting of $31 \%$ decreasers, $25 \%$ increasers III, 25\% increasers II, 13\% increaser I and 6\% forbs (Table 1). In terms of life form, $93 \%$ of grass species were perennials and $7 \%$ of creeping species (Table 1). In terms of abundancy, the burned site was dominated by palatable grasses such as Themeda triandra (14\%), Panicum Maximum (10\%), Cynodon dactylon (10\%) and Digitaria eriantha (9\%). Even though fire is not a selective tool, it is possible that some valuable species may survive fire and dominate an ecosystem.

Fire changes plant communities by reducing the dominance of some plant species, but may also stimulate the growth of others [26]. Despite stimulating the growth of the vegetation, fire also activates dormant seeds in the soil and influences species composition and forage production [23]. The unburned site was dominated by mixed species which includes Panicum Maximum (15\%), Themeda triandra (8\%), Alloterpsis semialata (8\%), Eragrostis curvula (9\%), Melica Decumbens (8\%) and forbs (13\%).

Plants such as Melica decumbens, forbs and Elionorus muticus were less abundant at the burned site compared to unburned site, these plants may have 
Table 1. Botanical name, ecological status, perenniality, nutritional value and relative abundance (\%) at unburned and burned sites.

\begin{tabular}{|c|c|c|c|c|}
\hline \multirow[b]{2}{*}{ Botanical name } & \multirow[b]{2}{*}{ Ecological status } & \multirow[b]{2}{*}{ Lifeform } & \multicolumn{2}{|c|}{$\begin{array}{c}\text { Relative } \\
\text { abundance (\%) }\end{array}$} \\
\hline & & & Unburned & Burned \\
\hline Alloterpsis semialata & Increaser I & Perennial & 8 & 8 \\
\hline Aristida diffusa & Increaser III & Perennial & 1 & 2 \\
\hline Cymbopogon validis & Increaser I & Perennial & 2 & 3 \\
\hline Cynodon dactylon & Increasers II & Creeping & 5 & 10 \\
\hline Digitaria eriantha & Decreaser & Perennial & 5 & 9 \\
\hline Elionorus muticus & Increaser III & Perennial & 6 & 1 \\
\hline Eragrostis capensis & Increaser II & Perennial & 1 & 3 \\
\hline Eragrostis curvula & Increaser II & Perennial & 9 & 9 \\
\hline Forbs & Not known & Not known & 13 & 5 \\
\hline Helictotrichon turgidulum & Decreaser & Perennial & 4 & 6 \\
\hline Melica Decumbens & Increaser III & Perennial & 8 & 4 \\
\hline Microchloa Caffra & Increaser II & Perennial & 7 & 5 \\
\hline Panicum Maximum & Decreaser & Perennial & 15 & 10 \\
\hline Seteria sphacelata & Decreaser & Perennial & 4 & 6 \\
\hline Sporobolus africanus & Increaser III & Perennial & 4 & 5 \\
\hline Themeda triandra & Decreaser & Perennial & 8 & 14 \\
\hline
\end{tabular}

been suppressed by fire at the burned site. The less abundance of forbs at the burned site compared to the unburned site, could be the fact that grasses may become more competitive and recovered faster after burning as compared forbs. This contradicts, [8], who reported that fire synchronize forb recruitment in burned compared to unburned areas. [23] demonstrated that grasses and forbs may respond differently in burned areas compared to unburned areas. After burning, species tend to compete for space, sunlight, soil resources, species that are good competitors happen to out-compete weaker competitors [8].

\subsection{Effect of Burning on Biomass Production}

Burned site had significantly $(\mathrm{P}<0.05)$ higher biomass production $(4804 \mathrm{~kg} / \mathrm{ha})$ compared to unburned site with the biomass production of $3641 \mathrm{~kg} / \mathrm{ha}$ (Figure 3). The results indicated that burning can improve biomass yield because fire removes dead plant material and also allows new growth to access sunlight. However, burning can also enhance grass nutritive quality, palatability and suppress unwanted plants. [26] reported higher biomass production at burned areas compared to unburned areas. Burning may improve nutritive value, availability and yield of grasses. [27] argued that biomass production may influenced by fire 


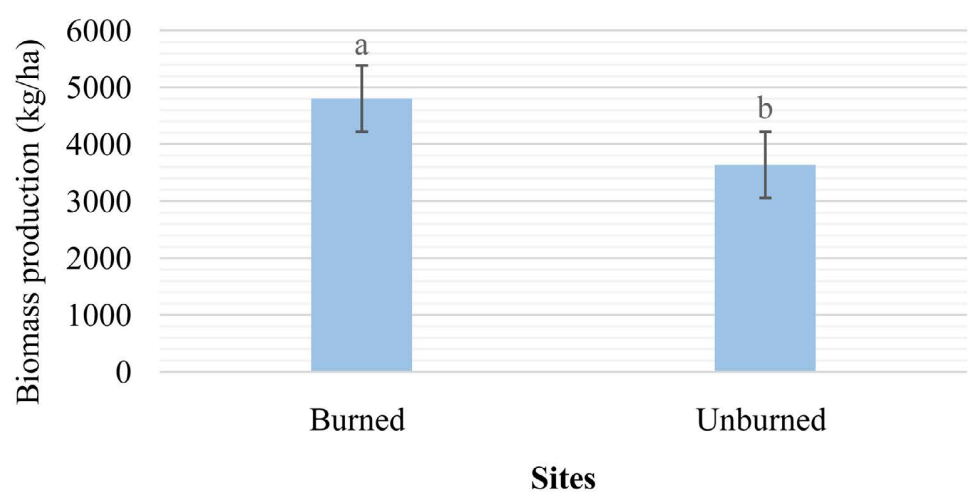

Figure 3. Biomass production $(\mathrm{kg} / \mathrm{ha})$ in burned and unburned site in Bathurst research station.

frequency and rainfall at burned regions. Furthermore, high dry matter yield at the burned confirms that fire has the stimulatory influence on the growth of some species and their litter production. Low dry matter production at unburned site may contributed by unremoved moribund around grass buds. The grass leaves grow from intercalary meristems and from new tillers from protected buds. Therefore, in the absence of fire tillers these may end up covered by moribund materials that could lead to slower growth rate of the vegetation in unburned areas [28]. Conversely, under burned areas new tillers are exposed to sunlight, they tend to grow quicker and result in higher grass biomass production [8]. Fire increases plant nutrients availability in the soil and act as a natural force in the development of grasses by stimulating seed germination [29].

\subsection{Effect of Burning on Woody Composition}

Thirteen woody plant species were identified, 54\% were acceptable (Brachylaena elliptica, Coddia rudis, Grewia occidentalis, Maytenus heterophylla, Scutia myrtia, Vachellia karoo) and 46\% were unacceptable (Diospyros lycioides, Lantana camara, Ptaeroxylon obliquum, Searsia pallens, Zanthoxylum capense and Trimeria trinervis) to browsers (Table 2). The dominance of acceptable woody plants showed a great potential for sustaining goat production and game farming. [20] reported $64 \%$ of acceptable and $36 \%$ of unacceptable woody plants species in the same province. Vachellia karoo (burned: 65.85\% and unburn: $13.70 \%$ ), Searsia pallens (burned: $26.83 \%$ and unburned: 6.85\%), Lantana camara (burned: $3.66 \%$ and unburned $9.59 \%$ ) and Diospyros lycioides (burned: $2.4 \%$ and unburn: $6.85 \%$ ) were most dominated species at both burned and unburned sites. High relative abundance of Vachellia karoo, Searsia pallens, Lantana camara and Diospyros lycioides at burned site may decline if burning is repeated with sufficient fuel load.

[29] suggested that single fire event may not only be sufficient in reducing the densities woody plants species, but may also stimulate its recruitment. The absence of Brachylaena elliptica, Coddia rudis, Grewia occidentalis, Maytenus heterophylla, and Zanthoxylum capense at burned site may have influenced by fire 
Table 2. Botanical name, acceptability and relative abundance (\%) at unburned and burned sites.

\begin{tabular}{ccccc}
\hline & & & \multicolumn{2}{c}{ Relative abundance (\%) } \\
\hline Botanical name & Local name & Acceptability & Unburned & Burned \\
\hline Brachylaena elliptica & Isiduli & Acceptable & 4.11 & - \\
Coddia rudis & Intsinde & Acceptable & 4.11 & - \\
Diospyros lycioides & Umbhongisa & Unacceptable & 6.85 & 2.44 \\
Grewia occidentalis & Umnqabaza & Acceptable & 31.51 & - \\
Lantana camara & Utywala bentaka & Unacceptable & 9.59 & 3.66 \\
Maytenus heterophylla & Umqaqoba & Acceptable & 1.37 & - \\
Ptaeroxylon obliquum & Umthathi & Unacceptable & 1.37 & - \\
Scutia myrtia & Isiphingo & Acceptable & 5.48 & 1.22 \\
Searsia pallens & Intlolokotshane & Unacceptable & 6.85 & 26.83 \\
Searsia incisa & Unongqutu & Acceptable & 6.86 & 1.22 \\
Vachellia karoo & Umnga & Acceptable & 13.70 & 65.85 \\
Zanthoxylum capense & Umnungwamabele & Unacceptable & 6.85 & - \\
Trimeria trinervis & Indlebendlovu & Unacceptable & 1.37 & - \\
\hline
\end{tabular}

intensity and fire tolerance. [30] reported that the response of woody plants to burning varies from species to species, some species are less tolerant than others.

\subsection{Effect of Burning on Woody Density and Browsing Unit}

Albany thicket is characterized by two continuous layers of both grasses and woody plants [2]. These two layers consists of both browse and non-browse species [31]. Browseable constitute plays a significant role on the diet of browsers such as goats, kudu etc. Therefore, it's vital to quantify the potential of rangeland or farm in terms of browsing capacity and density of woody plants. This study revealed that unburned site (5112 plants/ha) had the highest density of woody plants compared to burned site (3485 plants/ha) (Figure 4). The density of woody plants at burned site has shown that fire can kill trees but depending on the availability of fuel load and size of individual woody plant.

[31] reported that saplings are easily killed by fire as opposed to adult wood plants. Saplings have a thin bark with limited carbon storage are likely to face high post-fire mortalities [12]. Furthermore, number of plants per hectare revealed that burned and unburned were encroached (Figure 4). [32] mentioned that if woody plants per hectare exceed 2500 plant/ha, therefore that area is regarded as encroached. Bush encroachment may reduce the grazing capacity and biomass production [33] [34].

Burned site had the highest browsing unit (3221 BU/ha) compared to unburned site with the browsing unit (2058 BU/ha) (Figure 3). This study revealed that most of browseable woody plants at burned site were available to be 


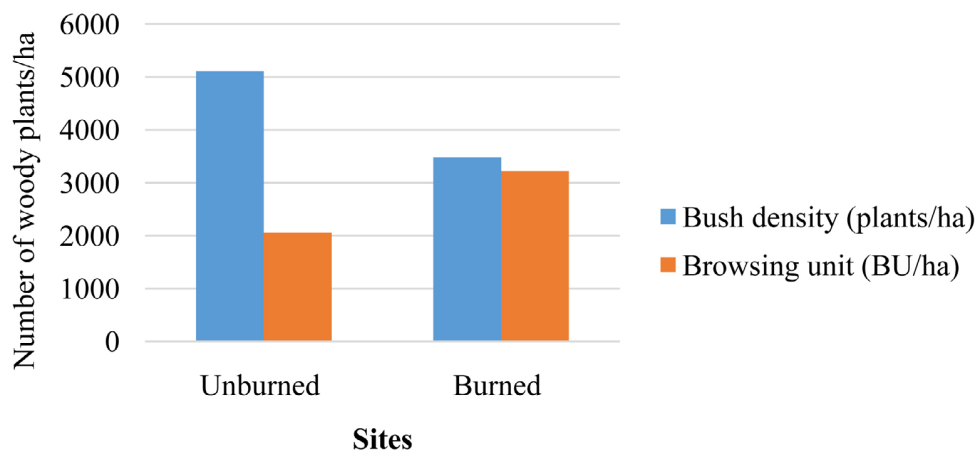

Figure 4. Woody density and browsing unit at burned and unburned in Bathurst research station.

browsed by browsers at the height of $1.5 \mathrm{~m}$. According to [31], $1.5 \mathrm{~m}$ height is known as a reachable height by browsers such as goats. This study showed that $54 \%$ of woody plants were browseable, thus, clearly showed that goats can be used in tandem with fire to control the coppicing after burning [35].

\section{Conclusion and Recommendations}

The results revealed that short-term burning yielded positive outcomes, and this was confirmed by the abundance of highly acceptable grasses (i.e. Themeda triandra, Panicum maximum, Cynodon dactylon and Digitaria eriantha) at burned site compared to unburned site. In terms of biomass production, similar trend was observed where burned site had more dry matter compared to unburned. However, short-term burning has shown potential for controlling or reducing wood plants as this was confirmed by significantly reduction of woody plant density at burned site. Burned site had high browsing unit compared to unburned site, which implies that most of the woody plants were within the reachable browsing height of $1.5 \mathrm{~m}$ for goats. This study recommends that further long-term trials need to be done to determine the effects of fire on rangeland vegetation.

\section{Acknowledgements}

The authors are indebted to the Bathurst and Dohne general workers for their assistance during the data collection and burning. We are also grateful to Dohne Agricultural Development Institute (ADI) and Department of Rural Development and Agrarian Reform (DRDAR) for permitting us to conduct this research.

\section{Conflicts of Interest}

The authors declare no conflicts of interest regarding the publication of this paper.

\section{References}

[1] Turpie, J., Botha, P., Coldrey, K., Forsythe, K., Knowles, T., Letley, G., Allen, J. and 
De Wet, R. (2019) Towards a Policy on Indigenous Bush Encroachment in South Africa. Department of Environmental Affairs, Pretoria.

[2] Lohmann, D., Tjetjen, B., Blaum, N., Joubert, D.F. and Jeltsch, F. (2014) Prescribed Fire as a Tool for Managing Shrub Encroachment in Semi-Arid Savanna Rangelands. Journal of Arid Environment, 107, 49-56. https://doi.org/10.1016/j.jaridenv.2014.04.003

[3] Schroter, M., Jakoby, O., Olbrich, R., Eichhorn, M. and Baumgartner, S. (2011) Remote Sensing of Bush Encroachment on Commercial Cattle Farms in Semi-Arid Rangelands in Namibia. In: Olej, V., Obrsalova, I. and Krupka, J., Eds., Environmental Modeling for Sustainable Regional Development. System Approaches and Advanced Methods, IGI Global. Hershey, 327-343.

https://doi.org/10.4018/978-1-60960-156-0.ch016

[4] Ward, D. (2005) Do We Understand the Causes of Bush Encroachment in African Savannas? African Journal of Rangeland and Forage Science, 22, 101-105. https://doi.org/10.2989/10220110509485867

[5] Warren, K., Hugo, W. and Wilson, H. (2018) Preliminary Report and Data on Bush Encroachment and Land Cover Change, Released to DEA Consultants and Selected Collaborators. Data Is Subject to Quality Assurance and Review. Department of Environment, forestry and Fisheries, Pretoria.

[6] United Nations (1992) United Nations Convention on Biological Diversity (CBD).

[7] Lisa, I., Michael J., Somers, I. and Fredrik. D. (2013) Effects of Prescribed Burning and Mechanical Bush Clearing on Ungulate Space Use in an African Savannah. Restoration Ecology, 21, 260-266. https://doi.org/10.1111/j.1526-100X.2012.00877.x

[8] Nepolo, E. and Mapaure, I. (2012) Short-Term Influence of Fire on Herbaceous Composition, Diversity and Grass Biomass Production in Semi-Arid Savanna Woodland in Winhoek, Namibia. International Journal of Ecosystem, 2, 154-160. https://doi.org/10.5923/j.ije.20120206.02

[9] Tokozwayo, S. (2016) Evaluating Farmers' Perceptions and the Impact of Bush Encroachment on Herbaceous Vegetation and Soil Nutrients in Sheshegu Communal Rangelands. M.Sc. Thesis, University of Fort Hare, Eastern Cape.

[10] Keeley, J.E. and Carrington, M.E. (1999) Comparison of Post-Fire Seedling Establishment between Scrub Communities in Mediterranean and Non-Mediterranean Climate Ecosystems. Journal of Ecology, 87, 1025-1036. https://doi.org/10.1046/j.1365-2745.1999.00419.x

[11] Mudongo, M., Rynn, R. and Bonyongo, M.C. (2015) Influence of Fire on Woody Vegetation Density, Cover and Structure at Tiisa Kalahari Ranch in Western Botswana. Grassland Science, 62, 3-11. https://doi.org/10.1111/grs.12110

[12] Higgins, S.I., Bond, W.J. and February, E.C. (2007) Effects of Four Decades of Fire Manipulation on Woody Vegetation Structure in Savanna. Ecology, 88, 1119-1125. https://doi.org/10.1890/06-1664

[13] Midgley, J.J., Lawes, M.J. and Chamaille-Jammes, S. (2010) Savanna Woody Plant Dynamics: The Role of Fire and Herbivory, Separately and Synergistically. Australia Journal of Botany, 58, 1-11. https://doi.org/10.1071/BT09034

[14] Enslin, B.W., Potgieter, A.L.F., Biggs, H.C. and Biggs. R. (2000) Long-Term Effects of Fire Frequency and Season on the Woody Vegetation Dynamics of the Sclerocarya Birrea/Acacia Nigrescens Savanna of the Kruger National Park. Koedoe, 43, Article No. a206. https://doi.org/10.4102/koedoe.v43i1.206

[15] Bond, W.J. and Van Wilgen, B. (1996) Fire and Plants: Population and Community 
Biology Series. Springer, Dordrecht. https://doi.org/10.1007/978-94-009-1499-5

[16] Smit, I.P.J, Asner, G.P., Govender, N., Kennedy-Bowdoin, T., Knapp, D.E. and Jacobson, J. (2010) Effects of Fire on Woody Vegetation Structure in African Savanna. Journal of Applied Ecology, 20, 1865-1875. https://doi.org/10.1890/09-0929.1

[17] Mucina, L. and Rutherford, M.C. (2006) The Vegetation of South Africa, Lesotho and Swaziland. South African National Biodiversity Institute, Pretoria, 348-437.

[18] Trollope, W.S.W. (1989) Veld Burning as a Veld Management Practices in Livestock Production. In: Danckwerts, J.E. and Teague, W.R., Eds., Veld management in the Eastern Cape, Government printer, Pretoria.

[19] Tokozwayo, S., Mopipi, K. and Timpong-Jones. E.C. (2021) Influence of Tree Density on Vegetation Composition and Soil Chemical Properties in Savanna Rangeland of Eastern Cape, South Africa. Journal of Agricultural Science, 12, 991-1002. https://doi.org/10.4236/as.2021.1210064

[20] Tokozwayo, S., Thubela1, T., Mthi, S., Nyangiwe, N., Khetani, T.L., Gulwa, U., Goni, S., Jansen, M., Qokweni, L. and Guza, B. (2021) Evaluation of Communal Rangeland Condition under the East Griqualand Veld Type of Eastern Cape Province, South Africa. Applied Animinal Husbandry Rural Development, 14, 1-8.

[21] Vetter, S., Goqwana, W.M., Bond, W.J. and Trollope, W.W. (2006) Effects of Land Tenure, Geology and Topography on Vegetation and Soils of Two Grassland Types in South. African Journal of Forage Science, 23, 13-27. https://doi.org/10.2989/10220110609485883

[22] Tefera, S., Snyaman, H.A. and Smit, G.N. (2007) Rangeland Dynamics of Southern Ethiopia: (2). Assessments of Woody Vegetation Structure in Relation to Land Use and Distance from Water in Semi-Arid Borana Rangelands. Journal of Environment and Management, 85, 443-452. https://doi.org/10.1016/j.jenvman.2006.10.008

[23] Oyedeji, O., Onuche, F.J., Animasaun, D.A., Ogunkunle, C.O., Agboola, O.O. and Isichei, A.O. (2016) Short-Term Effects of Early-Season Fire on Herbaceous Composition, Dry Matter Production and Soil Fertility in Guinea Savanna, Nigeria. Arch. Biological Science, 68, 7-16. https://doi.org/10.2298/ABS150526002O

[24] SAS Institute Inc. (2003) SAS Software. Frame Entry Usage and Reference. Version 8 , SAS Institute, Cary.

[25] Teague, W.R., Schelten, J.C. and Weitz, F.J. (1989) Recommended Agricultural Practices in the Mountain Vegetation of the Baviaanskloof-Kouga Complex Workshop. Kerely, G., Ed., Department of Zoology, University of Port Elizabeth, Port Elizabeth.

[26] Pyke, D.A., Brooks, M.L. and Antonio, C.D. (2010) Fire as a Restoration Tool: A Decision Framework for Predicting the Control or Enhancement of Plants Using Fire. Restoration Ecology, 18, 274-284. https://doi.org/10.1111/j.1526-100X.2010.00658.x

[27] Lance, T., Vermeire, J., Crowder, L. and Wester, D.B. (2011) Plant Community and Soil Environment Response to Summer Fire in the Northern Great Plains. Rangeland Ecology and Management, 64, 37-46. https://doi.org/10.2111/REM-D-10-00049.1

[28] Heinl, M., Silva, J. and Tacheba, B. (2004) Vegetation Changes after Single Fire in the Okavango Delta Wetland, Botswana. South African Journal of Botany, 70, 695-704. https://doi.org/10.1016/S0254-6299(15)30168-X

[29] Synman, H.A. (2003) Fire and the Dynamics of Semi-Arid Grassland: Influence of Plant Survival Reproductively and Water Use Efficiency. African Journal of Ran- 
geland and Forage Science, 20, 29-39. https://doi.org/10.2989/10220110309485795

[30] Timpong-Jones, E.C., Adogla-Bessa, T., Mugabe, P.H. and Adiku, S.G.K. (2012) Browisng Capacity and Nutritive Value of Indigenous Browses in a Tropical Coastal Savannah Rangeland. Bulletin of Animal Health and Production in Africa, 60, 335-342.

[31] Taylor, C.A., Twidwell, D., Garza, N.E., Rosser, C., Hoffman, J.K. and Brooks, T.D. (2012) Long-Term Effects of Fire, Livestock Herbivory Removal, and Weather Variability in Texas Semi-Arid Savanna. Rangeland Ecology and Management, 65, 21-30. https://doi.org/10.2111/REM-D-10-00124.1

[32] Abate, T., Ebro, A. and Nigatu, L. (2012) Evaluation of Rangeland in Arid and Semi-Arid Grazing Land of South East Ethiopia. International Journal of Agricultural Science, 2, 221-234.

[33] Gillson, L. and Hoffman, M.T. (2007) Rangeland Ecology in a Changing World. Journal of Agricultural Science, 315, 53-54.

[34] Graz, F.P. (2008) The Woody Weed Encroachment Puzzle: Gathering Pieces. Ecohydrology, 1, 340-348. https://doi.org/10.1002/eco.28

[35] Mndela. M. (2013) Evaluation of Range Condition, Soil Properties, Seed Banks and Farmer's Perceptions in Peddie Communal Rangeland. M.Sc. Thesis, University of Fort Hare, Eastern Cape. 